\title{
4
}

\section{Ageing in Australia: Population changes and responses}

\section{Peter McDonald}

Population ageing is the historical outcome of falling rates of fertility and mortality with fertility having the larger effect. While population ageing has only occupied the minds of policymakers since the 1980s, Australia's population has been ageing continuously for over a century. Figure 1 shows that ageing accelerated in the late 1920s and the 1930s. This was because of the substantial fall in fertility that occurred during the 1920s and the sustained low levels of fertility during the 1930s as a result of the economic depression (Figure 2). Counter to the long-term trend, the population stopped ageing in the 1950s and 1960s, this time as a result of the higher fertility that occurred during the 'baby boom' years. The number of births in Australia from 1946 to 1965 exceeded the number in the previous 20 -year period by 1.63 million births. Today, those born in the 1946-65 period are beginning to enter the retirement ages and are replacing the much smaller generation that was born from 1926 to 1945. This is why the rate of population ageing accelerates from 2010 through to 2040 (Figure 1) but this acceleration was not inevitable. It became so only because of falls in fertility and mortality rates from the mid-1970s onwards. 


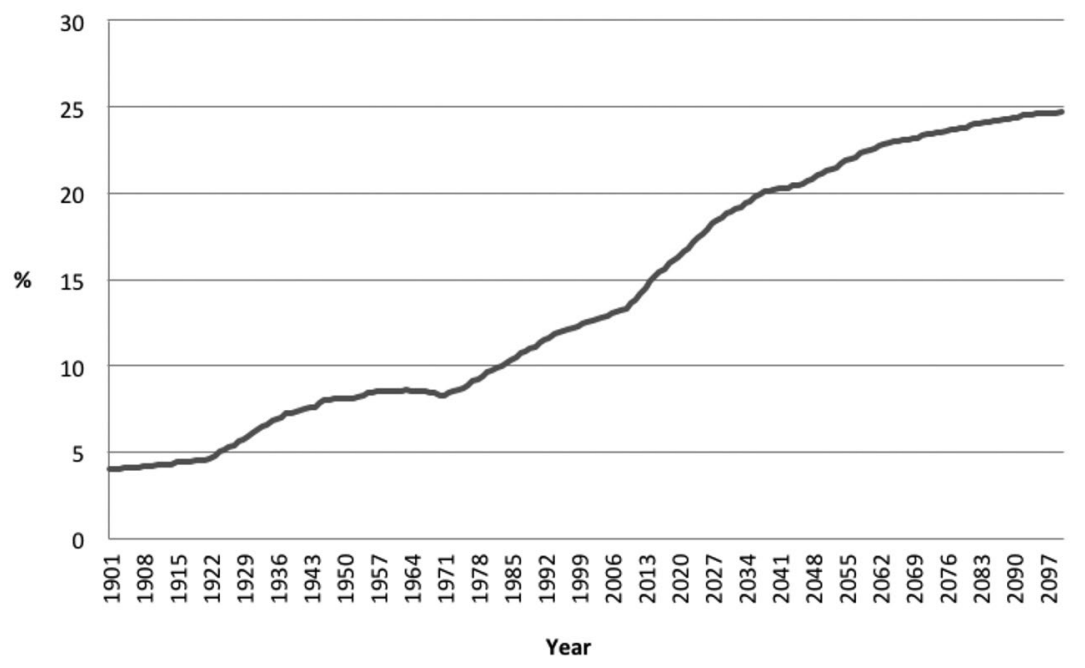

Figure 1. The percentage of the Australian population aged 65 years and over, 1901-2097

Sources: Produced by the author from Australian Bureau of Statistics. Australian Historical Population Statistics 2014. ABS Catalogue No. 3105.0.65.001. www. abs.gov.au/AUSSTATS/abs@.nsf/ProductsbyCatalogue/632CDC28637CF57ECA 256F1F0080EBCC?OpenDocument and Australian Bureau of Statistics (2013).

That the extent of population ageing today was not inevitable is illustrated by examination of the report of the National Population Inquiry (NPI) (1975). In the early 1970s, the Australian Government instigated a national population inquiry led by WD Borrie. In the Inquiry's report, the most comprehensive report on Australia's population ever undertaken, population ageing received only passing reference and no mention at all in relation to policy. Indicative population projections from 1970 to 2070 forecast that the proportion of the population aged 65 years and over would peak at between 9 and 15 per cent, with this peak being reached by 2030 (NPI 1975, 1: 294). In only two of the Inquiry's six indicative projections did the proportion aged 65 years and over peak at 12 per cent or more, a level that was in fact reached in 1996. The reason the Inquiry failed to predict the future level of population ageing is that the demography of Australia changed dramatically soon after the report was completed. 


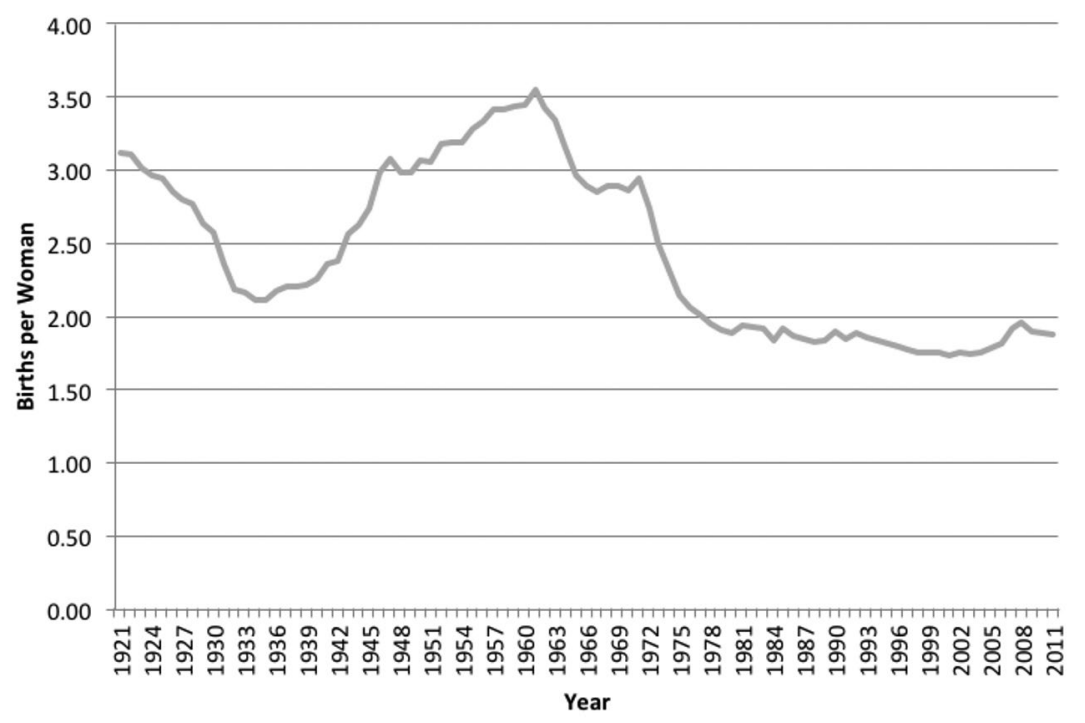

Figure 2. Total fertility rates, Australia, 1921-2011

Source: Produced by the author from Australian Bureau of Statistics. Australian Historical Population Statistics 2014. ABS Catalogue No. 3105.0.65.001. www. abs.gov.au/AUSSTATS/abs@.nsf/ProductsbyCatalogue/632CDC28637CF57ECA 256F1F0080EBCC?OpenDocument and Australian Bureau of Statistics (2015).

From around 1975, both fertility and mortality rates in Australia fell much more rapidly than had been assumed in the projections. The fertility rate in Australia in 1972, the last year for which the authors of the report had data, was 2.74 births per woman. By 1980, the rate had fallen to 1.89 births per woman and it has remained around that level ever since (Figure 2). Also from around 1972 onwards, death rates at older ages in Australia fell rapidly after having been almost constant in the previous 50 years (Figure 3). For example, in 1920-22, the expectation of life for Australian men at age 65 was 12 years. This was little changed at 12.2 years in 1970-72. However, by $2010-12$, it had increased significantly to 19.1 years. Thus, while it is often said that population ageing today is driven by the baby boom generation reaching the older ages, this is only the case because of the massive reductions in both fertility and mortality that occurred from the early 1970s onwards. 


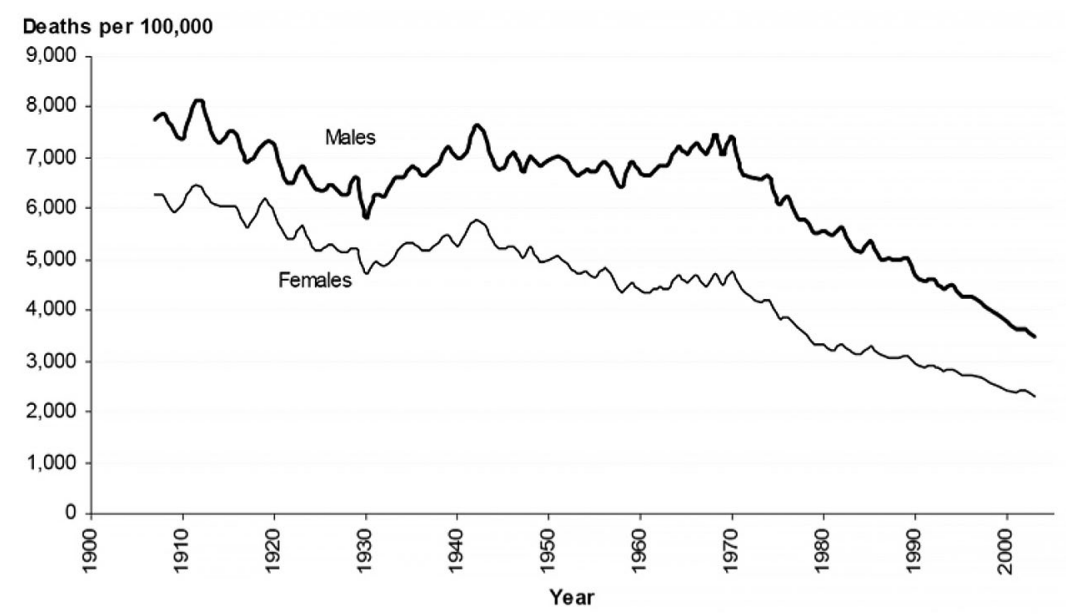

Figure 3. Age-specific death rates, 65-84 years, Australia, 1907-2003 Source. Australian Institute of Health and Welfare (2006), Figure 6.3: 109.

\section{Population ageing in Australia}

As shown in Figure 1, in the period 2012-36, ageing in Australia increases at a sharper rate than at any other time in the 200-year history shown in the figure. In numerical terms, the percentage of the population aged 65 years and over increases from 13.8 per cent in 2012 to 19.8 per cent in 2036. Subsequently, the speed of ageing slows. Figure 4 shows the changes in the age structure of the Australian population between 2011 and 2061 as estimated by the Australian Bureau of Statistics (ABS). The two age distributions are 'bee-hive' shaped, a relatively favourable outcome (McDonald and Kippen 1999) as the bulk of the population remains concentrated in the working ages and, by 2061, in the middle working ages rather the older working ages. As discussed below, this is a much more favourable outcome than most OECD countries, providing Australia with a relative advantage. The favourable outcome is the result of a relatively high fertility rate projected into the future in association with a high level of migration, with the migrants being mainly young adults. Table 1 shows the impact of four different levels of migration upon future levels of ageing in Australia. With zero net migration, the percentage of the population aged 65 years and over would increase from 14 per cent in 2013 to 28.4 per cent in 2053. With migration 
of 300,000 per annum, only 21.2 per cent of the population would be aged 65 years and over in 2053. The ABS projections shown in Figure 4 are based on the assumption that annual net migration will be 240,000 per annum. The percentages in the working ages, 15-64 years, move in the opposite direction, being six points higher with the high level of immigration compared with zero migration.

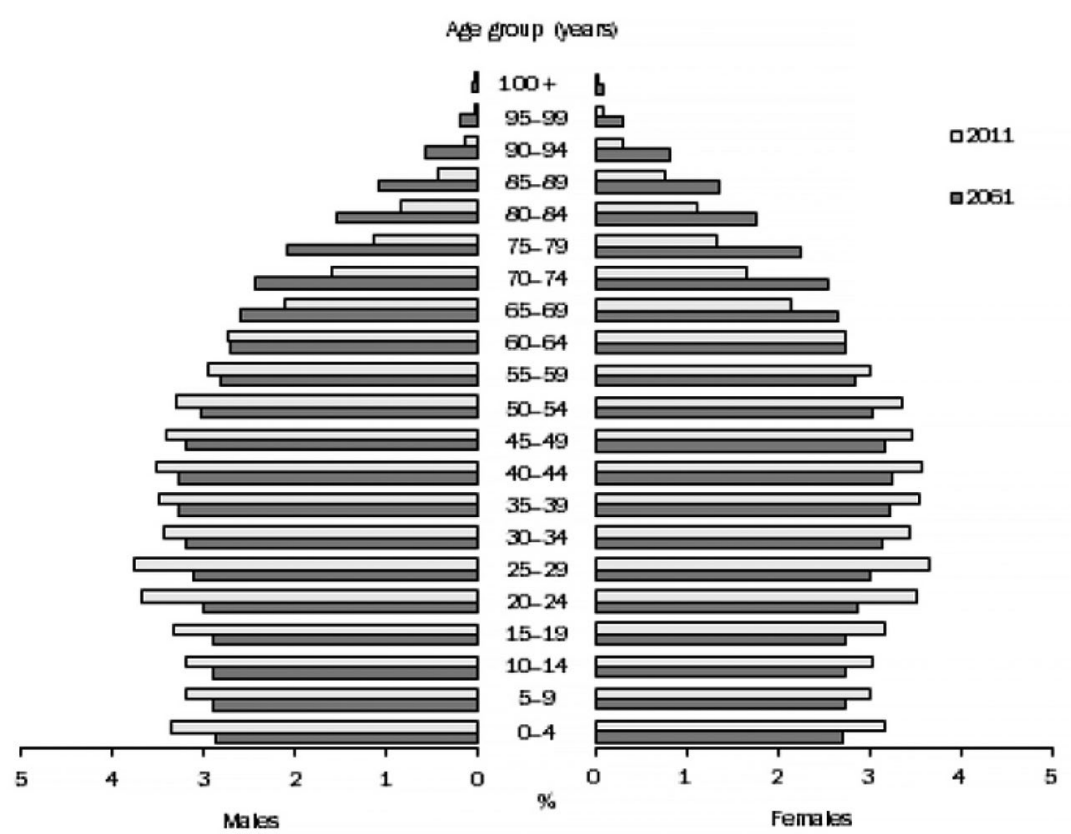

Figure 4. Australia's age distributions in 2011 and 2061

Source: Australian Bureau of Statistics (2013): 40.

Table 1. Long-term demographic assumptions in the 2002 and 2015 Intergenerational Reports and the 2003 and 2013 projections of the Australian Bureau of Statistics

\begin{tabular}{|l|c|c|c|c|}
\hline \multirow{2}{*}{} & \multirow{2}{*}{$\begin{array}{c}\text { Total fertility } \\
\text { rate (births } \\
\text { per woman) }\end{array}$} & \multirow{2}{*}{$\begin{array}{c}\text { Annual net } \\
\text { migration } \\
\end{array}$} & (000's) & \multicolumn{2}{|c|}{$\begin{array}{c}\text { Expectation of life at } \\
\text { birth in 2051(years) }\end{array}$} \\
\cline { 4 - 5 } & 1.6 & 90 & Males & Females \\
\hline IGR 2002 & 1.9 & 215 & 83.2 & 88.2 \\
\hline IGR 2015 & 1.6 & 100 & 87.5 & 90.1 \\
\hline ABS 2003 & 1.8 & 240 & 84.2 & 87.7 \\
\hline ABS 2013 & & 84.2 & 87.7 \\
\hline
\end{tabular}

Sources: Commonwealth of Australia (2015); Australian Bureau of Statistics (2003); Australian Bureau of Statistics (2013). 


\section{Why population ageing matters}

Population ageing matters to governments because of the typical age pattern of consumption and income as shown in Figure 5. Per capita consumption is much lower than per capita income at the older ages and becomes increasingly so as people get older. This deficit must be met from either public or private sources and, to the extent that the deficit is met from public sources, governments are faced with an increasingly more difficult fiscal situation the greater the proportion of the population in the older ages. This is shown more directly in Figure 6 in terms of government revenue and expenditure. Per capita expenditure exceeds per capita taxation from about age 62 onwards and the gap gets increasingly wider as age increases. In net terms, a typical 78-year-old costs all governments in Australia about $\$ 24,000$ per annum while the typical 43-year-old benefits government revenue by around $\$ 15,000$ per annum. The more the population consists of 78-year-olds rather than 43-year-olds, the greater the fiscal challenge for governments.

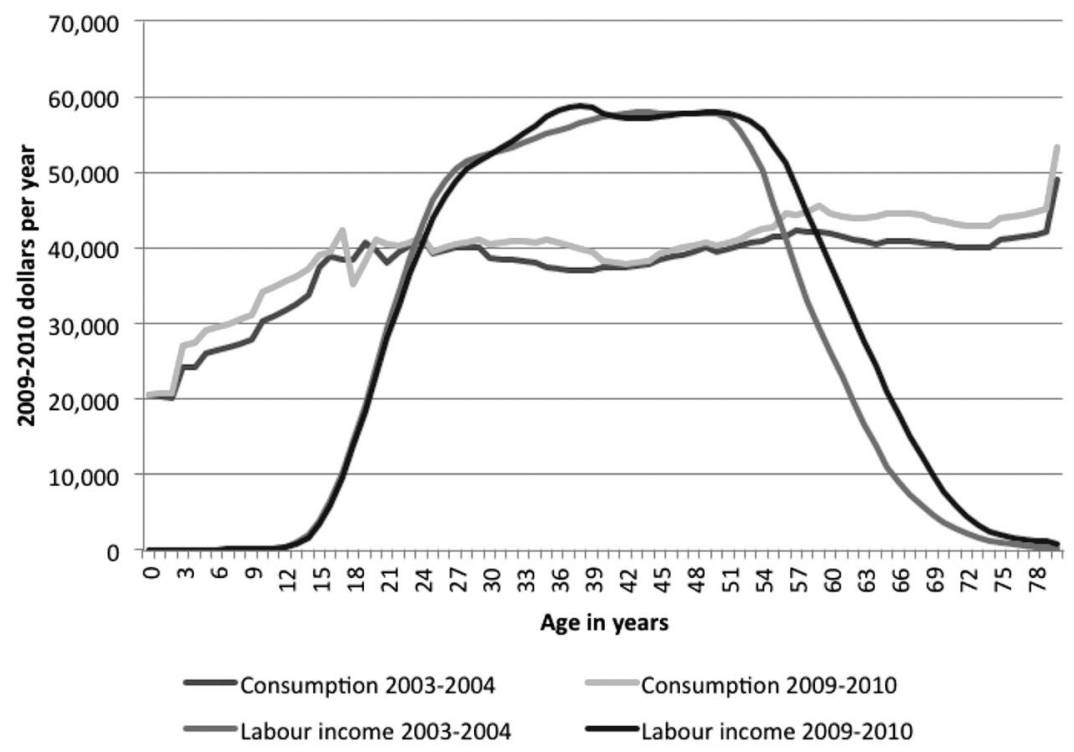

Figure 5. Per capita consumption and income by age, Australia, 2003-04 and 2009-10

Source: Rice, Temple and McDonald (2014): 11. 
This fiscal challenge is addressed by the Australian Government once every four years in the series of Intergenerational Reports (IGR) (Commonwealth of Australia 2002, 2007, 2010 and 2015). As required by the government's Charter of Budget Honesty Act 1998:

An Inter-Generational report is to assess the long term sustainability of current government policies over 40 years by taking account of the financial implications of demographic change (Commonwealth of Australia 2002: iii).

The first Intergenerational Report narrowed this to:

The report provides a basis for considering the Commonwealth's fiscal outlook over the long term, and identifying emerging issues associated with an ageing population (Commonwealth of Australia 2002: iii).

The models used in the IGRs treat demography as exogenous, that is, demography trends simply to occur without being influenced by the economic or social outcomes of the model. This is despite the fact that international migration is almost certainly endogenous, that is, a product of future social and economic trends, and its level is subject to government policy. The IGRs do not talk about migration as a policy instrument despite the growing body of literature (see below) showing that migration in the long term has substantial impacts on the economy and therefore upon the government's fiscal outcome. Fertility and mortality are 'less endogenous' than migration but expenditure on health interventions reduces mortality and international comparisons show that work-family policy explains why some advanced economies have very low fertility and others do not (McDonald 2006).

The implicit IGR assumption is that demographic trends are slow to change. Accordingly, the demography can be included as an assumed input model without much danger of being wrong. However, if we compare the demographic assumptions of the 2003 IGR with those used in the 2015 IGR (Table 2), they are substantially different, indicating that the demography can change in a relatively short time-frame. An increase in the fertility rate from 1.6 to 1.9 births per woman may not appear to be a large change but the implications are substantial. An increase in annual net migration from 90,000 to 215,000 per annum is obviously considerable and, as demonstrated below, has a large impact on population and economic outcomes. Finally, the increases in the assumed expectation of life at birth in 2050 are 1.9 years higher for women and 4.3 years higher for men. 
These changes imply a considerable increase in joint survival of partnered people. In relation to aged care, partners are the leading carers implying fiscal savings for governments as the providers of nonfamilial care.

Table 2. Impact of varying levels of net annual overseas migration on the age structure of the Australian population in 2053

\begin{tabular}{|l|c|c|}
\hline $\begin{array}{l}\text { Level of net annual } \\
\text { overseas migration }\end{array}$ & $\begin{array}{c}\text { Per cent of population } \\
\text { aged 15-64 in 2053 (\%) }\end{array}$ & $\begin{array}{c}\text { Per cent of population aged } \\
65 \text { and over in 2053 (\%) }\end{array}$ \\
\hline 0 & 56 & 28.4 \\
\hline 100,000 & 58 & 25.2 \\
\hline 180,000 & 60 & 23.4 \\
\hline 300,000 & 62 & 21.2 \\
\hline Per cent in 2013 & 67 & 14.0 \\
\hline
\end{tabular}

Source: McDonald and Temple (2013).

The age structure effects of the changes in the demographic assumptions across the IGR reports is illustrated by considering the effects of similar changes in assumptions made in the ABS population projections published in 2003 and 2013 (Figure 7). ${ }^{1}$ The figure shows by how much the 2051 projected population increased in each age group due to the changes in assumptions made in the 2003 ABS projections and in the 2013 ABS projections. The bar for age group 0-9 means that the $0-9$ population in 2051 is 78 per cent higher in the 2013 ABS projections than it was in the 2003 projections. This means the future child population in 2051 almost doubles simply because of changes in the assumptions about future demography.

This large increase is due both to assumed fertility moving up from 1.6 to 1.9 births per woman and to the additional births born to net migration being 125,000 per annum higher in the 2013 projections than was assumed for the 2003 projections. It is sometimes said in error that migration does not slow the ageing of the population because migrants also age. The statement is wrong because, besides the fact that migrants with an average age at arrival of 25 years are younger on average than the general population (37.3 years), migrants also have a lot of births before they get old. Indeed, they have grandchildren before they get old.

1 The ABS projections are used because the age structure outcomes in the IGR projections are not published. 


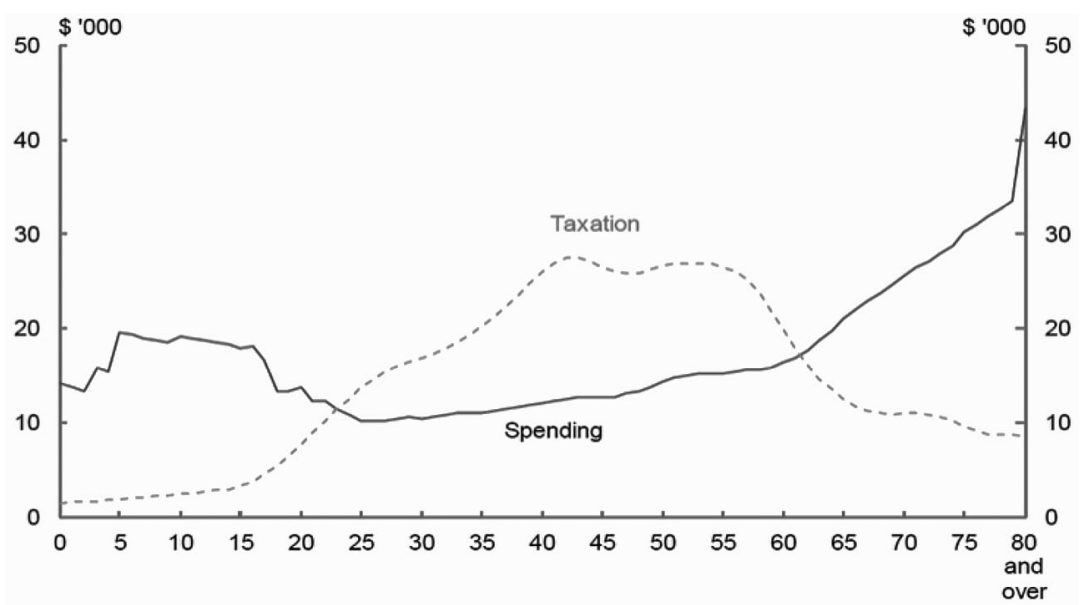

Figure 6. Per capita total government spending and taxes by age (total government means the Australian Government and State and Territory Governments), 2009-10

Source: Commonwealth of Australia (2015): 58, using data from Rice, Temple and McDonald (2014).

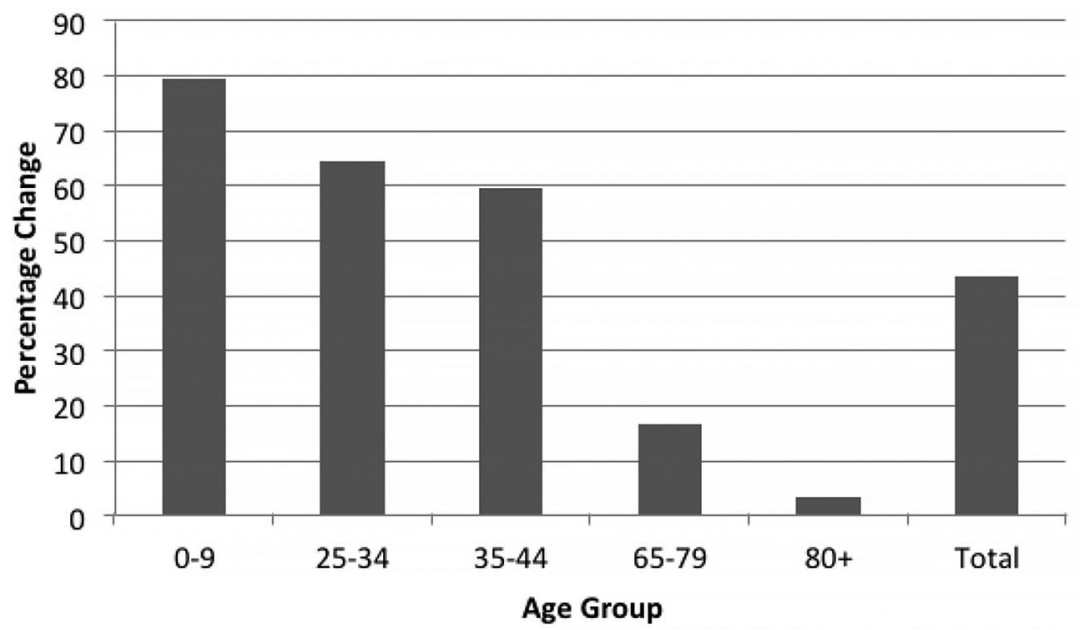

Figure 7. Percentage increase in the population in each age group in 2051 due to changes in the demographic assumptions made between the ABS 2003 and 2013 official population projections

Source: Produced by the author from data published in Australian Bureau of Statistics (2003) and Australian Bureau of Statistics (2013). 
The changes in assumptions between the two projections also substantially increase the numbers in the young working ages (25-34 and 35-44) but the numbers at older ages do not increase very much at all, especially for the old-old age group (80+). If there is one demographic certainty, it is that, over 40 years, a projection of the population aged 80 and over will be relatively accurate as it will be affected only by errors in the mortality assumption. So, shifting from the 2003 IGR to the 2015 IGR, the future population of Australia becomes much younger. This has the following implications.

In relation to consumption (public and private), it makes no difference whether the person is age 15 or 79 or any age in between (Figure 5). The profile of age-specific consumption is flat. Consumption is lower for children under 15 and higher for those aged 80 and over. Importantly, this means that consumption expenditure is relatively resilient to changes in age structure. The real issue with ageing of the population is on the income side of the equation. Figure 5 shows that aggregate income is highly susceptible to changes in age structure. It also shows what a huge benefit it was to the aggregate bottom line that employment rates increased for persons aged 55 and over between 2003-04 and 2009-10. In relation to the fiscal bottom line, more children are a problem in the short-term because their income is far less than their consumption. But further out, the additional children already born since the 2003 IGR was published enter the labour force just at the time that the baby boom generation hits the old-old ages. This will have obvious benefits for the fiscal outcome. Furthermore, the additional children have been born to more educated women and to skilled migrants, thus we can expect them to have high levels of human capital when they hit the labour market.

The shape of income and expenditure for governments (Figure 6) is a little different from the aggregate (private and public) income and expenditure shown in Figure 4. Government expenditure is higher for children than for working-age Australians and rises with age from age 25 onwards and sharply from age 60 onwards. Taxation revenue mirrors the aggregate income curve of Figure 4 except for the fact that children and older people are also tax generators. This is particularly the case in relation to the Goods and Services Tax (GST). In 2009-10 dollars, the average 13-year-old generated $\$ 1,500$ per annum in GST and it would be a lot more if the GST was levied on fresh food and education, both major private expenditures 
for 13-year-olds. The average 80 -year-old also pays about $\$ 1,500$ in GST and this also would be a lot more if the GST covered fresh food. Income tax, not unexpectedly, is closely related to income-earning and this is the key reason that changes in age structure put governments under fiscal pressure.

In summary, the income side of the government's fiscal situation is much more sensitive to changes in age structure than is the expenditure side. It is important that government expenditure is efficient and equitable and there are many improvements that can be made in this regard, but given the sensitivity of budgets to income rather than to expenditure as the age structure changes and with the successive IGRs consistently showing massive increases in living standards over the 40 years, it seems reasonable to think that much of the solution to population ageing may lie on the income side of the equation. Aside from taxation, the income side of the government's equation is aided by migration and by increases in labour force participation, and government fiscal outcomes swing massively on future growth in labour productivity. All three of the three Ps (productivity, participation and population), therefore, have important impacts in the context of population ageing.

\section{The impact of immigration on future GDP per capita}

Per capita gross domestic product, a frequently used measure of living standard, is the product of the employment to population ratio and output per worker. If the employment to population ratio falls because of population ageing, GDP per capita will also fall unless there is a commensurate rise in output per worker (labour productivity). However, the Australian employment to population ratio rises with increases in migration (McDonald and Temple 2013). This means that if labour productivity is at least as high for migrants as it is for non-migrants, migration will increase the growth rate of GDP per capita. The effect of varying migration levels upon the future growth rate of GDP per capita in Australia is shown in Figure 7, under the assumption that labour productivity is the same for migrants as for non-migrants, and its growth rate is constant across the projection period at 1.6 per cent per annum. The ageing of the population 
(fall in the employment to population ratio) has a large impact on the growth rate of GDP per capita between 2013 and 2023 because of the retirement from the labour force of the baby boom generation. For example, with zero migration, the growth rate of GDP per capita would fall from 1.83 per cent in 2013 to 1.33 per cent in 2023 simply because of the ageing of the population. The figure shows that this impact is mitigated to a meaningful extent by migration both in the short-term and the long-term. The impact of the additional births to migrants has an evident secondary impact on the growth of GDP per capita in the 2030s and 2040s.

Beyond this employment to population ratio effect on the growth of GDP per capita, if migrants are more skilled than non-migrants or if migrants fill pivotal roles in new investment endeavours, migration will also have the effect of increasing labour productivity. There is some evidence that this is the case in that the education levels of migrants are well above the general education level of the population. Furthermore, contrary to the popular perception, two studies have shown that migration in Australia, through its stimulatory effects, increases the wages of low-wage workers (Peri, Docquier and Ozden 2010; Migration Council of Australia 2015). In the international comparative study, this result was only evident for two countries, Australia and Singapore, both of which run large skilled migration programs (Peri, Docquier and Ozden 2010).

There is also an argument that young workers are an important source of economic dynamism and that they are the assimilators of new technology in each era of new technology (McDonald and Temple 2006). The skilled migration program that Australia runs substantially shifts the median age of the labour force to a younger age than would be the case with no migration. Many new skilled immigrants are recent graduates of the Australian university system and therefore can be expected to have skills that are well honed to the needs of the Australian labour market (Migration Council of Australia 2015). Over the next 40 years, largely because of migration, Australia will experience significant increases in the number of its young workers. Many other OECD countries will experience the opposite: rapidly declining numbers in the young working ages. 


\section{International comparisons of population ageing}

Among OECD countries, there is a bifurcation of countries according to the current level of fertility. One set of countries, that includes all of the Nordic countries, all of the English-speaking countries and all of the French- and Dutch-speaking countries, have fertility rates of 1.7 births per woman and above. The other set of countries, that includes all of the Southern European countries, all of the Germanspeaking countries and all of the advanced East Asian countries (including China), have fertility rates that are below 1.5 births per woman (McDonald 2006). Population ageing is much more severe in countries with very low fertility.

Across countries, there is considerable variation in the speed and extent of population ageing. Essentially, there are two groups of countries: those where fertility fell to near-replacement level by the 1930s and those where fertility has fallen from the 1950s onwards. For the first group of countries, essentially European countries and the advanced English-speaking countries, the most rapid period of ageing is from 2010 to 2030, mainly because most of these countries experienced post-war baby booms and all have experienced falls in mortality rates at older ages since the 1970s. The baby boom was largest in the United States, Canada, Australia and New Zealand and moderately large in almost all Western and Northern European countries but small in the Southern European countries (van Bavel and Reher 2013). However, as described above for Australia, contemporary ageing is also affected by the levels of fertility and migration since the 1970s. Variations in ageing across these countries from 2010 to 2030 are shown in Figure 8. By 2030, Australia will be the 'youngest' of all of these countries according to the United Nations, followed by the other English-speaking countries and then the Nordic countries. As these were the countries that had the largest baby booms, it is evident that the relatively high levels of fertility in all of these countries, and for some high levels of migration, have offset the ageing effect of the baby boom generation to some extent. Despite relatively low fertility and a sizeable baby boom, Switzerland ages only slowly between 2010 and 2030 because of its expected high levels of migration. The 'oldest' of these countries will be Italy and Germany because of sustained low levels of fertility. 


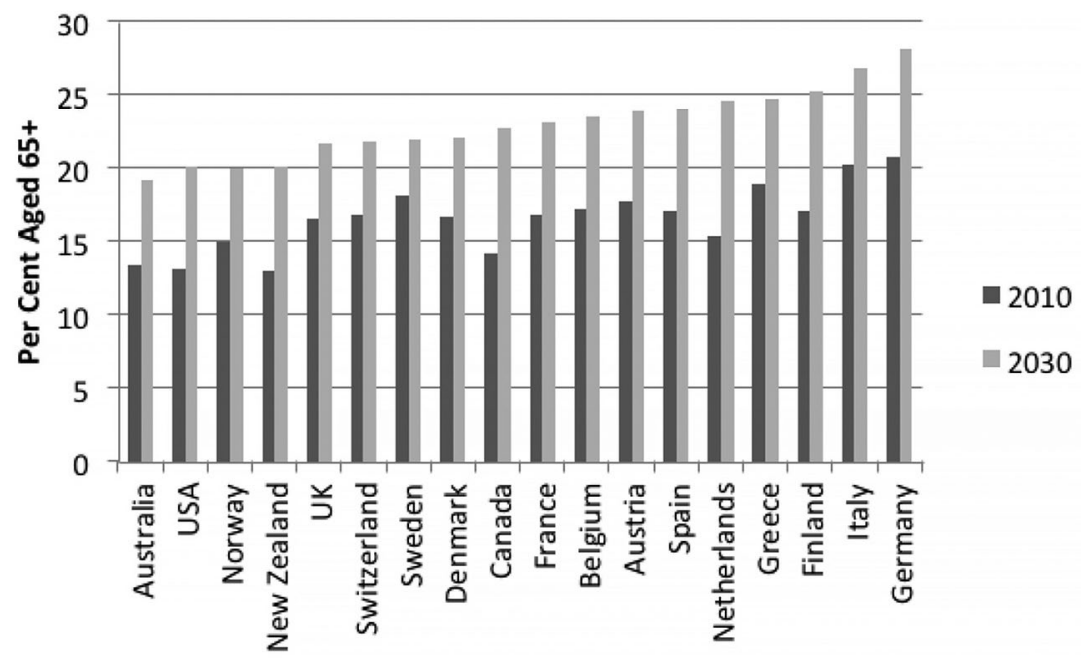

Figure 8. Percentage of population aged 65 years and over, 2010 and 2030

Source: United Nations, Department of Economic and Social Affairs, Population Division: esa. un.org/unpd/wpp/unpp/panel_indicators.htm.

In the countries where fertility has fallen from high levels only since the 1950s, ageing is determined by the speed, recentness and level of the country's fertility decline. When the fertility rate falls rapidly, a large generation is followed fairly closely by a small generation. When the large generation reaches the older ages the subsequent smaller generations are in the working ages, leading to rapid population ageing. The recentness of the fertility decline, of course, determines the time at which the large generation reaches the older ages. Finally, the extent of the fertility decline, the most important of the three factors, determines the difference in the sizes of the successive generations. There seems also to be a relationship between the speed and the level of the decline. Countries that experienced a very rapid fall in fertility tend also to be the countries where fertility has fallen to very low levels (under 1.5 births per woman). 
Figure 9 shows the extent of ageing across selected Asian countries from 2010 to 2050. In the countries where ageing is not so prominent in 2050 (the Philippines, India, Indonesia and Malaysia), fertility has fallen slowly over the past $40-50$ years and still remains above the replacement level. For the other countries in Figure 9 (except for Japan), the extent of population ageing is very great in the next 40 years. This is because fertility fell very rapidly between 1970 and 2000 in these countries and, in China, ${ }^{2}$ Singapore, Thailand and Korea, fertility has fallen to very low levels. Japan was older in 2010 than most of the countries in Figure 8 will be in 2030, and it gets much older over the next 50 years. This is essentially the result of very low fertility sustained over a long period.

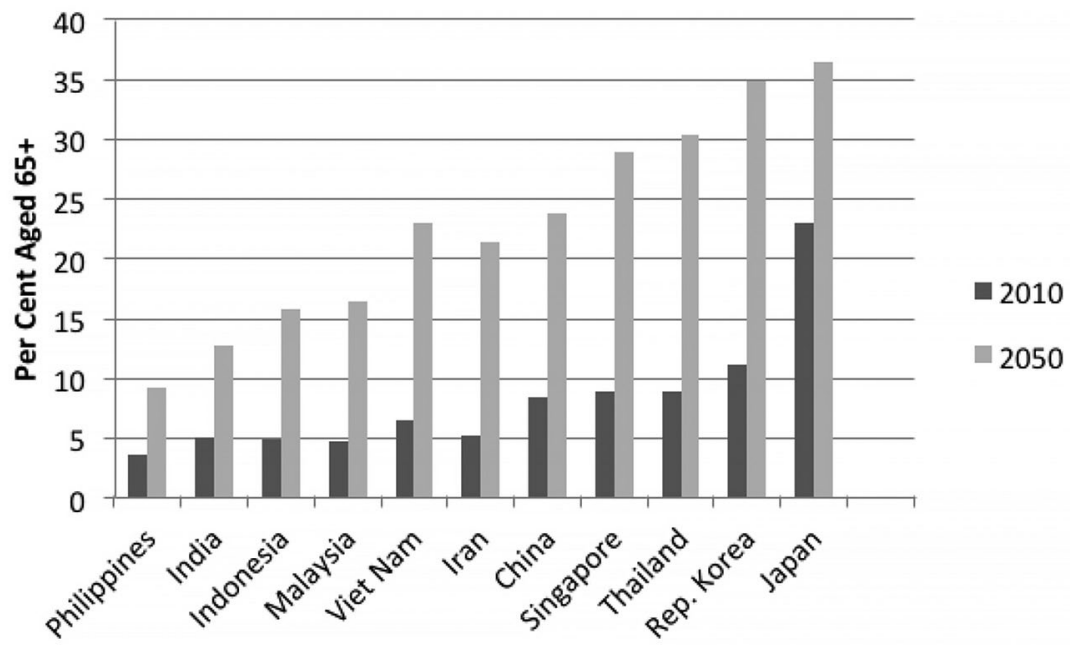

Figure 9. Percentage of population aged 65 years and over, 2010 and 2050

Source: United Nations, Department of Economic and Social Affairs, Population Division. esa. un.org/unpd/wpp/unpp/panel_indicators.htm.

2 The Wittgenstein Centre also produces population projections for all countries of the world. Its projection of the percentage of the population of China aged 65 years and over in 2050 ( 28 per cent) is much higher than the United Nations level shown in Figure 9 ( 23 per cent) (Lutz, Butz and KC 2014). The two agencies differ on what is the current level of fertility in China. I consider that the Wittgenstein Centre estimate is more reliable. Differences for other countries shown in Figures 8 and 9 are small. 


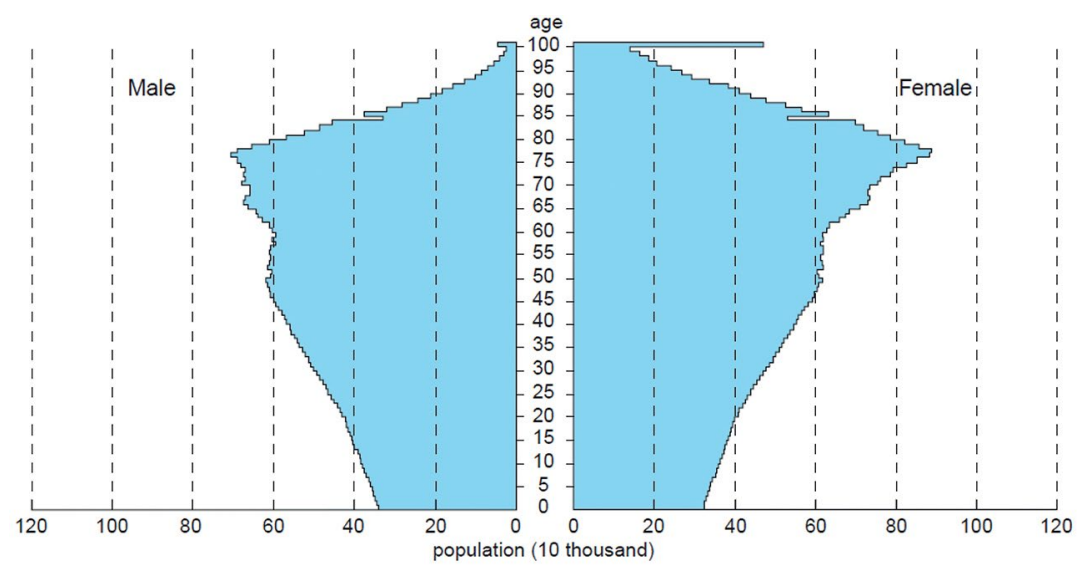

Figure 10. The 2050 age distribution of Japan

Source: National Institute of Population and Social Security Research (2002): 11.

The age distribution of Japan in 2050 (Figure 10) contrasts dramatically with that of Australia (Figure 4). In Japan in 2050, the largest numbers of people are aged between 75 and 80 and the age structure tapers downwards with ever smaller numbers as the age gets younger. The working-age population is comparatively old with a considerable shortage of young workers. This age structure has been referred to as the 'coffin' shape (McDonald and Kippen 1999) and, indeed, if the demography of Japan were to remain unchanged, the population would largely disappear in the 100 years after 2050. For many years, the Government of Japan has been attempting to raise the fertility rate so that the longer-term future is rosier than this, but, to date, fertility has remained below 1.5 births per woman and Japan is still heading on this trajectory. If the fertility rate were to increase in the future, the Japanese economy would still face a major struggle to support its aged population before the new larger generation reached the labour force ages. There are no easy solutions to this dilemma, especially when Japan already has a high debt to GDP ratio. 


\section{Concluding remark}

The Intergenerational Reports produced by the Department of Treasury have focused on the challenges that Australia faces because of population ageing. These challenges are addressed in other chapters. However, it is important to note that with every successive IGR, the projected population is relatively younger than in the previous one. This is because the Australian fertility rate has risen and is close to the replacement rate and because the level of international migration has increased substantially. It is important that these favourable demographic trends continue. As shown in the analysis above, by 2030, Australia will be the youngest among the Englishspeaking countries and the countries of Western Europe. It will also be younger than many of the current advanced economies in Asia. Thus, from the demographic perspective, Australia is in a favourable position. This means that accommodating to population ageing becomes a matter of long-term sensible planning not hasty shortterm fixes.

\section{References}

Australian Bureau of Statistics (2003). Population Projections Australia, 2002-2101. Canberra: ABS Australian Bureau of Statistics.

Australian Bureau of Statistics (2013). Population Projections, Australia. ABS Cat. No. 3222.0. Canberra: Australian Bureau of Statistics.

Australian Bureau of Statistics (2015). Australian Demographic Statistics, September 2014. ABS Cat. No. 3101.0. Canberra: Australian Bureau of Statistics.

Australian Institute of Health and Welfare (AIHW) (2006). Mortality over the twentieth century in Australia: Trends and patterns in major causes of death. Cat. no. PHE 73. Canberra: AIHW.

Commonwealth of Australia (2002). Intergenerational Report: 2002-03. Canberra: Department of Treasury. 
Commonwealth of Australia (2007). Intergenerational Report: 2007. Canberra: Department of Treasury.

Commonwealth of Australia (2010). Australia to 2050: Future Challenges. The 2010 Intergenerational Report. Canberra: Department of Treasury.

Commonwealth of Australia (2015). 2015 Intergenerational Report: Australia in 2055. Canberra: Department of Treasury.

Lutz Wolfgang, Butz William and KC Samir (2014). World Population and Human Capital in the 21st Century. Oxford: Oxford University Press.

McDonald Peter (2006). Low fertility and the state: The efficacy of policy. Population and Development Review, 32(3): 485-510.

McDonald Peter and Kippen Rebecca (1999). Population futures for Australia: The policy alternatives. Parliamentary Library Seminar Series, Research Paper No. 5, 1999, Canberra: Australian Parliamentary Library.

McDonald Peter and Temple Jeromy (2006). Immigration and the Supply of Complex Problem Solvers in the Australian Economy. Canberra: Department of Immigration and Multicultural Affairs. www.immi.gov.au/media/publications/research/index.htm.

McDonald Peter and Temple Jeromy (2013). The Long Term Effects of Ageing and Immigration upon Labour Supply and Per Capita Gross Domestic Product: Australia 2012-2062, Final Report, Canberra, October.

Migration Council of Australia (2015). The Economic Impact of Migration. Canberra: Migration Council of Australia.

National Institute of Population and Social Security Research (NIPSSR) (2002). Population Projections for Japan: 2001-2050. Tokyo: NIPSSR.

National Population Inquiry (1975). Population and Australia: A Demographic Analysis and Projection, 2 volumes. Canberra: Australian Government Publishing Service. 
Peri Giovanni, Docquier Frederic and Ozden Cagler (2010). The Wage Effects of Immigration and Emigration, NBER Working Paper No. 16646.

Rice James, Temple Jeromy and McDonald Peter (2014). National Transfer Accounts for Australia: 2003-04 and 2009-10 Detailed Results. ARC Centre of Excellence in Population Ageing Research and Crawford School of Public Policy, The Australian National University. www.cepar.edu.au/media/134354/nta_report_2014.pdf.

van Bavel Jan and Reher David (2013). The baby boom and its causes: what we know and what we don't know. Population and Development Review, 39(2): 257-288. 
This text is taken from Population Ageing and Australia's Future, edited by Hal Kendig, Peter McDonald and John Piggott, published 2016 by ANU Press, The Australian National University, Canberra, Australia. 